
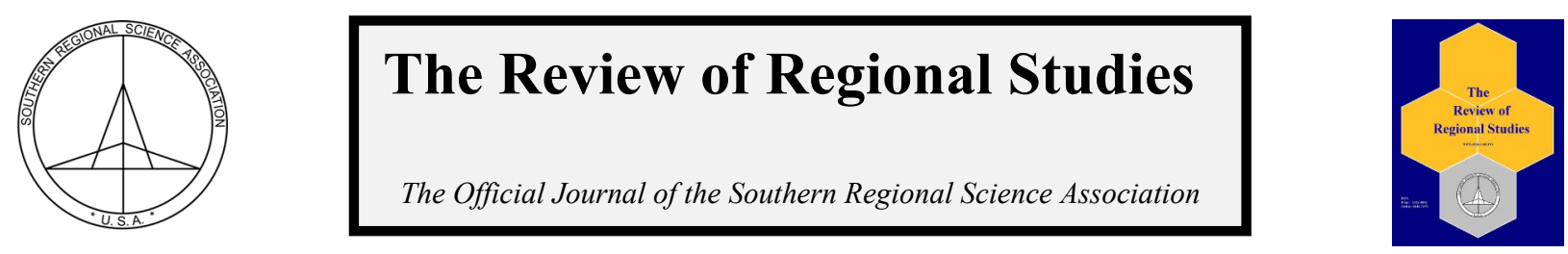

\title{
The Responsiveness of Tax Lien Investors in English Auctions to Matching Rules: Evidence from Illinois ${ }^{*}$
}

\author{
Joshua J. Miller ${ }^{\mathrm{a}}$ and Silda Nikaj ${ }^{\mathrm{b}}$ \\ ${ }^{a}$ Department of Economics, University of Illinois at Chicago, USA \\ ${ }^{b}$ Department of Economics, Texas Christian University, USA
}

\begin{abstract}
Auctions allowing competitors to match the current high bid are thought to be suboptimal, particularly compared to auctions where new bids must exceed the current high bid (Milgrom, 2004). To date no study has examined, empirically, the effect of allowing matching bids. A recent policy innovation in Illinois provides an opportunity to estimate the effect of matching on winning bids. Using administrative data from five suburban Illinois counties on the auction of 127,073 liens, we find that an English auction design that allows matching is associated with higher winning bids when compared to an English design that does not allow matching. These higher winning bids increase interest fees on tax delinquent property owners by 20 percent. The paper is the first to estimate the cost of matching on auction outcomes.
\end{abstract}

Keywords: auction design, property tax

JEL Codes: D44, H71, R12

\section{INTRODUCTION}

The National Tax Lien Association estimates that $\$ 21$ billion in property taxes become delinquent each year and $\$ 6$ billion in delinquent tax liability is offered at tax lien sales annually. A tax lien sale is the sale of delinquent property taxes by a local government to investors. In 2011, local governments in 23 states conducted tax lien sales. The primary method of sale is auction. Auction design varies by state and sometimes within states.

Although local governments in the United States have used tax lien sales since 1819 (Carlson, 1951; Swierenga, 1974) and there is a literature that suggests that bidders respond to differences in auction designs (Milgrom, 2004), there remains little empirical evidence on the effect of auction design on bidder behaviors. Estimating the responsiveness of bidders to different auction designs has important implications about the cost of tax delinquency for property owners. To the extent that local governments have discretion in choosing auction designs, the costs of delinquency may be reduced. This is especially true given significant increases in tax delinquency in many large cities during the Great Recession. ${ }^{1}$

\footnotetext{
* We are grateful to editor Michael L. Lahr and two anonymous referees for their invaluable comments. We also thank Nathan B. Anderson, Rebecca M. Hendrick, Robert Kaestner, David F. Merriman, and Joseph J. Persky for helpful guidance. We thank participants of the Southern Economic Association Annual Meeting for insightful comments and discussion.

Miller is a Housing Policy Economist. Nikaj is an Assistant Professor of Economics. Corresponding Author: Silda Nikaj, e-mail: s.nikaj@tcu.edu

${ }^{1}$ See for example, Kerkstra (2013).
}

C) Southern Regional Science Association 2013.

ISSN 1553-0892, 0048-749X (online)

www.srsa.org/rrs 
In this analysis we are the first to exploit a policy innovation in Illinois. This policy allows county treasurers to choose the tax lien sale auction design. The ability to choose enables measurement of the effect of auction design on bidder behavior. More specifically we compare outcomes between two auction designs, the standard English auction, which forces new bids to exceed the current highest bid (nonmatching), and a modified English auction that allows new bids to match the current highest bid rather than having to exceed it (matching). We use administrative data from the auction of 127,073 liens in five suburban counties bordering the city of Chicago from 2005 to 2011, and find that the English matching design is associated with a 20 percent increase in the cost of tax delinquency for property owners over that they incur via the standard design. The average property owner in the English matching auction with an outstanding tax delinquency of $\$ 4,496$ paid $\$ 117$ more in the first year of delinquency when compared to similar liens offered in the English nonmatching design. While the choice of auction design is endogenous, we argue that county treasurers did not choose these auction designs to affect winning bids: Rather they chose them to reduce administrative and financial burdens that sales impose on local governments. The findings show that the association between matching rules and winning bids is robust to different sample restrictions suggesting that the relationship is likely causal. An untested maintained hypothesis of the regression model is that the auction format affects auction outcomes. Furthermore, the findings directly support the observation and untested hypothesis of a previous study by Milgrom (2004). The results are important not only to the design of tax lien auctions but are applicable to the design of other auctions with experienced bidders.

\section{TAX LIEN SALE AUCTION DESIGN}

Although Illinois state law allows counties to determine their own tax lien sale auction design, state law dictates some rules common to all tax lien sale auctions. County governments offer liens in sequential order one parcel at a time by township and property identification number (PIN). In all counties, investors bid on individual liens by declaring an interest rate between 18 and 0 percent. Bids are entered in whole percentage point increments (i.e. $0,1,2, \ldots, 18)$. The bidder with the lowest interest rate wins the right to pay the delinquent property taxes in exchange for repayment plus interest. The property lien is transferred from the county to the winning bidder as collateral. Interest rates of 18 percent represent a low price for investors, in which case the investor earns the highest possible interest permitted by state law. Interest rates of zero represent a high price as winning bidders earn no interest during the first year of delinquency. Zero interest-rate bids are common in the observed sample. Winning bidders who purchase liens at any interest rate gain first rights to purchase all subsequent delinquency on the same property at a fixed rate of 18 percent, according to Illinois law. Liens not sold at auction are returned to the county at an interest rate of 18 percent.

The two auction designs compared in our analysis are English matching and English nonmatching (the standard English auction). In the English matching auction, investors submit a bid by raising a paddle. The auction concludes when only one bidder remains at the lowest interest rate charged or multiple bidders with matching bids are unwilling to bid at a lower interest rate. In cases where more than one investor offers the same low bid, the county treasurer chooses a winner at random. It is rare for liens sold to investors not to receive more than one bid at the same low rate; often, ten or more investors bid the same interest rate.

(C) Southern Regional Science Association 2013. 
In a standard English auction, investors submit a bid by selecting the desired interest rate on a computer screen. All bidders and computers are located in the same room. The first bidder to select the lowest interest rate wins the right to purchase the lien. It is not possible in the English nonmatching auction design for more than one bidder to register the same interest rate.

\section{THEORETICAL MODEL}

In this section, we argue that tax lien sales are common value auctions and show that matching rules affect winning bids. We describe the bidding strategy under each design and discuss the implications of matching rules on winning bids.

Tax lien sales are common value auctions because the monetary benefit of lien ownership, which is unknown at the time of bidding, does not vary across investors (Menezes and Monteiro, 2005). Our description of the monetary payoff from lien ownership and the optimal bidding strategy assumes that there are no nonpecuniary benefits to lien ownership. An example of a nonpecuniary benefit would be the additional benefit derived from purchasing the lien on a property close to a family relative. Liens are purchased by investors for the interest earned when property owners pay the delinquent tax bill. Liens are rarely purchased by individuals with the long-term goal of personally occupying the property. For example, from 2005 to 2011, our sample includes only 98 liens that were sold to investors participating in one auction and purchasing one lien. This represents less than 0.1 percent of all liens sold to private investors.

In order to derive the optimal bidding strategy for a sequential common value auction, we first model the bidder's expected payoff. When purchasing a lien, the bidder faces two possible outcomes: redemption or tax foreclosure. In redemption, the property owner pays the delinquent tax bill plus interest. In tax foreclosure, the tax delinquent property owner is forced to relinquish property rights.

Winning bidders purchase liens by paying the delinquent tax bill at time $t$. The payoff from redemption occurs at a time period prior to tax foreclosure, $t+1$, whereby the winning bidder receives the delinquent tax bill at $t$ plus any interest that accrued since. More formally, let $D$ denote the delinquent tax bill and $l_{i}$ the interest-rate bid submitted. Equation (1) provides the present value payoff with redemption.

$$
\text { Payoff with tax redemption }=\frac{D\left(1+l_{i}\right)}{\left(1+r_{i}\right)}-D
$$

In tax foreclosure, the winning bidder obtains ownership of the property in $t+2$. The payoff in tax foreclosure is the property market value at tax foreclosure minus the delinquent tax bill and interest. More specifically, let $D$ represent the delinquent tax bill and $V$ the market value of the property at tax foreclosure. Then the payoff with tax foreclosure is provided by Equation (2). The payoff for the winning bidder is the discounted value of property minus the delinquent tax bill purchased.

$$
\text { Payoff with tax foreclosure }=\frac{V}{\left(1+r_{i}\right)^{2}}-D
$$

Suppose that $\pi$ is the probability of redemption, then Equation (3) shows the investor's expected payoff function. The expected payoff is equal to the probability of redemption 
multiplied by the payoff in redemption plus the probability of tax foreclosure, $(1-\pi)$, multiplied by the payoff in tax foreclosure.

$$
E_{(t)}^{I}=\pi \frac{D\left(1+l_{i}\right)}{\left(1+r_{i}\right)}+(1-\pi) \frac{V}{\left(1+r_{i}\right)^{2}}-D
$$

The expected payoff of lien ownership is a function of the probability of redemption, the delinquent tax bill, the estimated property value at tax foreclosure, and the investor's opportunity cost. In practice, the probability of redemption is unobservable by the investor. An investor's estimate of the probability of redemption varies across properties according to observable property characteristics. The estimated probability of redemption is a function of whether the tax-delinquent property owner finds total outstanding liabilities, including the delinquent tax bill and interest accrued, to be greater than the property's market value at tax foreclosure. The estimated probability of redemption is affected by the delinquent tax bill, the estimated property market value at tax foreclosure, and the interest rate.

From Equation (3), one can solve the minimum interest rate, $\bar{l}_{i}$, beyond which no investor will bid. The minimum interest rate is that at which the expected payoff to zero.

$$
\bar{l}_{i}=\frac{D\left(1+r_{i}\right)^{2}-(1-\pi) V-\left(1+r_{i}\right) D \pi}{\left(1+r_{i}\right) D \pi}
$$

Equation (4) shows that as the probability of redemption approaches one, $\pi=1$, the minimum interest rate bid approaches $r_{i}$, the investor's cost of capital. An investor will not bid an interest rate below the next best investment alternative when redemption is certain. Similarly, as the probability of redemption approaches zero, $\pi=0$, the minimum bid approaches zero percent provided a positive payoff at tax foreclosure. The payoff with an interest rate bid of 18 percent is identical to an interest rate bid of 0 percent when tax foreclosure is certain. If investors are certain that tax foreclosure will take place and the property value exceeds the opportunity costs, the optimal bid is zero because it is not possible for competing investors to submit a lower bid.

\subsection{English Auction}

The minimum interest rate represents the lower bound for investors. In a competitive market, such as a sequential common value English auction with many bidders, the expected payoff will approach zero and the interest rate will approach the minimum interest rate. At English auctions, once the sale begins, investors use the bids of other investors to update estimates of the probability of redemption and estimates of property market value at tax foreclosure. After the market-based estimates are established, the only difference in expected payoffs across investors is idiosyncratic differences in investor's cost of capital.

From Equation (4), we can update the market minimum lien interest rate, $\bar{l}_{m}$, beyond which no investor bids. The minimum interest rate is the interest rate at which the expected payoff to zero.

$$
\bar{l}_{m}=\frac{D\left(1+r_{i}\right)^{2}-(1-\pi) V-\left(1+r_{i}\right) D \pi}{\left(1+r_{i}\right) D \pi}
$$

(C) Southern Regional Science Association 2013. 
The market interest rate is the symmetric Bayesian Nash equilibrium. The optimal bidding strategy for all investors in the English, sequential common-value auction is to bid the market interest rate.

The two auction designs using the English auction type differ with respect to rules on matching. In observing the 1996 Cook County tax-lien sale auction, Milgrom (2004) noted that 80 percent of all liens sold at the maximum interest rate of 18 percent. Milgrom attributed the poor auction result to problematic rules on matching.

In the English nonmatching auction design, the market interest rate is the symmetric Bayesian Nash Equilibrium for all investors. An investor's interest rate bid below the market interest rate bid, $\bar{l}_{m}>\bar{l}_{i}$, would result in continual overpayment. The literature refers to the phenomenon as the "winners curse" (Milgrom and Weber, 1982; Milgrom, 2004). Rational actors are unwilling to pay more than the market value of any good of common value when bids are revealed. An investor's interest rate bids above the market interest rate bid, $\bar{l}_{m}<\bar{l}_{i}$, should result in no liens being purchased. Therefore, investors in the standard English auction design should bid the market interest rate, provided the investor's cost of capital does not exceed the interest rate.

In the English matching design, the market interest rate represents the lower bound as multiple investors are permitted to enter a bid at the market interest rate. The Pareto optimal solution for investors is to enter a bid above the market interest rate. For example, imagine three investors with an opportunity cost of three percent. Each investor is willing to purchase the lien for at most three percent when the probability of redemption approaches one. In the English nonmatching design, the first investor to bid three percent wins the right to purchase the lien with absolute certainty. In the English matching design, all three investors can enter identical bids of three percent and face a one-third probability of winning the right to purchase the lien. The same three investors, however, could instead choose to enter a bid of 18 percent and face the same one-third probability of winning the right to purchase the lien (Milgrom, 2004). In this scenario, the market interest rate is not a Pareto optimal bidding strategy.

The Pareto optimal bidding strategy may be realized without overt collusion. But both open bidding and auction rules that allow matching engender tacit collusion. Open bids means investors get to observe the bidding strategy of others. Thus, auction that allow bid matching encourage noncompetitive behavior. Reducing interest-rate bids in the English-matching design does not necessarily increase the probability of winning. The bidding strategy in the Englishmatching design is for the investor to equate the marginal cost with the marginal benefit of reducing the interest-rate bid. The marginal cost of reducing the interest rate by one percentage point is exactly that one percentage point less in interest earned. The marginal benefit of reducing the interest rate by one percentage point is an increase in the probability of winning the right to purchase the lien as investors with higher opportunity costs drop out of the auction.

The theoretical prediction for the winning bid in a standard English auction is that it will equal the market interest rate. The bidding strategy in the English-matching design is greater than or equal to the market interest rate. Therefore, the interest charged to the tax delinquent property owners will be higher in the English-matching auction design as winning bids in the English matching auction are greater than or equal to the optimal interest rate for an equivalent in a standard English auction. 


\section{LITERATURE REVIEW}

The theoretical literature examining the effect of auction design on revenue is extensive (Milgrom and Weber, 1982; McAffee and McMillan, 1987). But as yet no empirical work estimates the effect of matching rules on winning bids. Although no prior work examines the effect of matching rules on winning bids, two previous studies (DeBoer et al., 1992; Allen et al., 2004) identify determinants of tax-lien sale auction results. Using data from the 1987 tax lien sale held in Marion County, Indiana, DeBoer et al. (1992) find that assessed value, minimum bid, property location, property type, and auction order are important determinants of probability of sale and winning bids. In the study, properties with higher assessed value were more likely to sell to investors and had higher winning bids. For every $\$ 1,000$ increase in the assessed value the probability of sale increased by 0.008 . Additionally a 1.0 percent increase in the assessed value increased the winning bid by 0.99 percent. Assessed value serves as a proxy of market value, and higher market values result in greater payoffs in tax foreclosure (Conrad and DeBoer, 1990).

Properties with higher reserve prices were less likely to sell at auction, and such reserve prices had little effect on winning bids. For every $\$ 1,000$ increase in the reserve price, the probability of sale fell by 0.023 (DeBoer et al., 1992). Auction theory supports the finding that higher reserve prices decrease the probability of sale (Kagel and Levin, 2002).

Liens offered toward the end of the auction were less likely to sell, and when sold, generally did so at lower winning bids. The findings support the hypothesis that bidders are quantity constrained, and bid until demand is satisfied (DeBoer et al., 1992). The authors also found that liens located in the central city were less likely to sell and, when sold, received lower winning bids. Clearly investors expected lower payoffs on central-city properties when compared to properties not located in the central city. Liens on single-family homes were more likely to sell at auction and sold at a higher winning bid when compared to liens on vacant property (DeBoer et al., 1992).

In a separate study, Allen at al. (2004) used auction results for 166,316 delinquent parcels in Palm Beach County, Florida, from 1982 to 2000 to examine potential determinants of winning bids. In Florida, investors enter bids as interest rates. Higher bids entered by investors represent a low price for investors and lower bids entered by investors represent as high price for investors. The novelty of the study was to include controls for buyer size. The authors separate buyers into three mutually exclusive categories; small buyers purchasing fewer than 10 liens, medium buyers purchasing 10 to 100 liens, and large buyers purchasing more than 100 liens. The authors found that large buyers paid a higher price (lower bids) for liens when compared to small and medium buyers. It is likely that large buyers have lower capital costs and compete with other larger buyers to purchase liens with a high probability of redemption.

We found no prior study that examines the effect of matching rules on winning bids. The present paper apparently is the first.

\section{DATA SOURCES, VARIABLE CONSTRUCTION, AND EMPIRICAL SPECIFICATION}

The study sample includes data from five counties located in the northeast corner of Illinois. The five counties are suburban to the city of Chicago. Cook County is not one of them. Researchers commonly refer to the counties as the "collar" counties (Dye and McGuire, 1997). The collar counties are similar to one another in terms of economic and demographic 
characteristics. From 2005 to 2011, years for which data are available, we observe 14 auctions using the English-matching design and 16 using the standard English-auction design. In the study period, two counties used the English-matching design (Kane and McHenry Counties) and two counties used the standard English design (DuPage and Will Counties). Lake County switched from English matching to English nonmatching design in 2007. The data include information on liens offered, liens sold, winning bids, delinquent tax bills, assessed value, property type, auction order, property location, and buyer's name.

Tables 1, 2, and 3 provide descriptive statistics for all auctions observed. The collar counties sold approximately 90 percent of all liens offered and 97 percent of all property tax delinquencies offered to private investors during the period of observation. There was no significant difference in the type or amount of liens sold between the two designs. Table 1 shows that most unsold liens were vacant properties with little market value. Across all designs and all counties, winning bids ranged from 0 to 18 percent with a median of 3 and mean of 6.3 percent.

We estimate the effect of matching rules on winning bids, using the following model.

$$
\text { Interest }_{l t}=\alpha_{0}+\beta_{1} E_{l}+\beta_{2} X_{l}+S_{l t}+I_{l}+T_{l}+\lambda_{t}+\varepsilon
$$

The outcome variable, Interest $t_{l}$, is the winning interest rate of lien $l$ at year $t$. The interest rate takes values between 0 and 18 percent. The variable in which we are interested, $E_{l}$, is equal to one if the lien was offered at the English nonmatching design and zero otherwise. The comparison group for the analysis is liens offered using the English matching design. $X_{i}$ is a vector of property characteristics, which includes the determinants of winning bids discussed in the literature (DeBoer et al., 1992; Allen et al., 2004).

TABLE 1: Auction Descriptive Statistics I

\begin{tabular}{|c|c|c|c|c|c|c|}
\hline & \multicolumn{3}{|c|}{ Sold } & \multicolumn{3}{|c|}{ Unsold } \\
\hline & No. Liens & $\begin{array}{c}\text { Mean } \\
\text { Delinquent } \\
\text { Tax Bill }(\$) \sim\end{array}$ & $\begin{array}{c}\text { Percent } \\
\text { Residential } \\
\text { Improved }\end{array}$ & No. Liens & $\begin{array}{c}\text { Mean } \\
\text { Delinquent } \\
\text { Tax Bill }(\$) \sim\end{array}$ & $\begin{array}{c}\text { Percent } \\
\text { Residential } \\
\text { Improved }\end{array}$ \\
\hline English - Matching & 44,997 & $\$ 4,494$ & $68.7 \%$ & 4,552 & $\$ 1,180$ & $0.2 \%$ \\
\hline English - Non-Matching & 70,347 & $\$ 5,115$ & $72.7 \%$ & 7,316 & $\$ 1,043$ & $3.7 \%$ \\
\hline
\end{tabular}

(C) Southern Regional Science Association 2013. 
TABLE 2: Auction Descriptive Statistics II

\begin{tabular}{|c|c|c|c|c|c|c|}
\hline & \multicolumn{2}{|c|}{ No. Liens } & \multicolumn{2}{|c|}{ Tax Delinquency $\sim$} & \multicolumn{2}{|c|}{$\begin{array}{c}\text { Winning Interest } \\
\text { Rate* }\end{array}$} \\
\hline & Offered & $\begin{array}{l}\text { Percent } \\
\text { Sold to } \\
\text { Private } \\
\end{array}$ & Offered & $\begin{array}{l}\text { Percent } \\
\text { Sold to } \\
\text { Private }\end{array}$ & Mean & Median \\
\hline English - Matching & 35,221 & $90.1 \%$ & $\$ 152,426.3$ & $96.9 \%$ & 9.3 & 5.0 \\
\hline English - Non-Matching & 72,134 & $90.4 \%$ & $\$ 346,928.3$ & $97.9 \%$ & 5.6 & 3.0 \\
\hline
\end{tabular}

Note: Adjsuted for inflation and presented in thousands of 2011 \$, * Liens sold to private investors

TABLE 3: Auction Descriptive Statistics III

\begin{tabular}{|c|c|c|c|c|c|c|}
\hline \multirow[b]{2}{*}{ English - Matching } & \multicolumn{2}{|c|}{ No. Liens } & \multicolumn{2}{|c|}{ Tax Delinquency } & \multicolumn{2}{|c|}{ Mean } \\
\hline & Purchased & Percent & Purchased & Percent & $\begin{array}{c}\text { Winning } \\
\text { Interest } \\
\text { Rate }\end{array}$ & $\begin{array}{l}\text { Delinquent } \\
\text { Tax Bill }\end{array}$ \\
\hline $\begin{array}{c}\text { Large Buyers } \\
\text { (100 or more liens) }\end{array}$ & 18,919 & $59.6 \%$ & $\$ 91,369.8$ & $61.8 \%$ & 8.5 & $\$ 4,830$ \\
\hline $\begin{array}{l}\text { Meduim Buyers } \\
\text { (10 to } 99 \text { liens) }\end{array}$ & 12,277 & $38.7 \%$ & $\$ 54,038.6$ & $36.6 \%$ & 7.6 & $\$ 4,402$ \\
\hline $\begin{array}{l}\text { Small Buyers } \\
\text { (1 to } 9 \text { liens) }\end{array}$ & 528 & $1.7 \%$ & $\$ 2,333.5$ & $1.6 \%$ & 9.2 & $\$ 4,420$ \\
\hline English - Non-Matching & Purchased & Percent & Purchased & Percent & $\begin{array}{c}\text { Winning } \\
\text { Interest } \\
\text { Rate } \\
\end{array}$ & $\begin{array}{c}\text { Delinquent } \\
\text { Tax Bill }\end{array}$ \\
\hline $\begin{array}{c}\text { Large Buyers } \\
\text { (100 or more liens) }\end{array}$ & 50,112 & $76.8 \%$ & $\$ 265,203.1$ & $78.1 \%$ & 4.3 & $\$ 5,292$ \\
\hline $\begin{array}{l}\text { Meduim Buyers } \\
\text { (10 to } 99 \text { liens) }\end{array}$ & 13,866 & $21.3 \%$ & $\$ 69,720.8$ & $20.5 \%$ & 4.3 & $\$ 5,028$ \\
\hline $\begin{array}{l}\text { Small Buyers } \\
\text { (1 to } 9 \text { liens) }\end{array}$ & 1,232 & $1.9 \%$ & $\$ 4,597.7$ & $1.4 \%$ & 5.6 & $\$ 3,732$ \\
\hline
\end{tabular}

Note: Buyer volume was measured at each auction. For example a large buyer in the 2010 Kane County annual tax sale purchased 100 or more liens during that auction not including previous activity. Liens purchased by the counties are not included in the count.

$\sim$ Adjsuted for inflation and presented in thousands of 2011 \$

We control for minimum bid, estimated market value, property location, property type, and the order in which the lien was offered for sale. We view the delinquent tax bill as the minimum bid for an interest-rate auction. The delinquent tax bill is reported in thousands of 2011 dollars. Properties with higher reserve prices are expected to be sold at higher prices or lower winning bids (DeBoer et al., 1992).

We use assessed value as a proxy for the estimated market value of the property. The assessment ratio in Illinois is one third. We compute the estimated market value by multiplying 
assessed value by three. Estimated property market value is measured in thousands of 2011 dollars. We expect that higher estimated market values to lead to lower winning bids (DeBoer et al., 1992).

To measure the impact of property type on winning bids we separate property type in this dataset into three mutually exclusive categories. The first property type is residential improved, which represents approximately two-thirds of all observations. Residential improved property includes single-family dwellings, multifamily dwellings, condo-units, and apartment buildings. The second property type is vacant property, which represents about a quarter of all observations. The third property type is all "other improved property," which includes commercial and industrial. We expect residential improved properties to be sold at higher prices (lower winning bids). The excluded category is "other improved property."

The declining price anomaly suggests that the auction order affects winning bids (Ashenfelter, 1989; Ashenfelter and Genesove, 1992; Mezzitti, 2011). It is possible that liens sold at the beginning of the auction receive different winning bids than similar liens sold at the end. To account for this possibility, we create a dummy variable indicating whether the lien was offered late in the auction. The variable is set equal to 1 if the lien was offered in the last quarter of the auction and 0 otherwise.

We include a spatial lag of the dependent variable, $S_{l t}$, as a control in our estimation (Anselin, 2002; Anselin, 2003; Anselin and Arribas-Bel, 2013). The spatial lag variable was created at the township-year level by property type; it includes the mean winning bid in neighboring townships. We use a queen contiguity weighting matrix. We experimented with a rook contiguity matrix, which produced similar results for our variable of interest (English nonmatching). Similar properties should sell for similar winning bids when located in proximity to one another, ceteris paribus. Thus inclusion of the variable assures that our results are not spurious or subject to omitted variable bias. One interpretation of the spatial lag may be that winning bids on nearby properties proxy for investors' perceived opportunity costs when bidding on a property. We also address serial correlation in the error within township over time by clustering errors at the township level.

By construction the spatial lag is correlated with the error term and thus endogenous. This endogeneity can be solved through either maximum likelihood estimation or instrumental variables (Anselin, 2002). We employ a standard approach in this literature, and use the spatial lag of market value as an instrument in predicting the spatial lag of the winning bid (Anselin and Arribas-Bel, 2013).

DeBoer et al. (1992) find property location to be an important determinant of the probability of sale and winning bid. We therefore control for property location using township fixed effects $T_{l}$. Furthermore we include year fixed effects to account for trends in tax-lien sales unique to the year in which the tax lien was held.

Tax-lien sale investors vary by the number of liens they purchase, the types of liens purchased, experience, and their access to capital (Conrad and DeBoer, 1990). Previous research has found that large-volume investors - those purchasing 100 or more liens at any one auctionpurchase at lower interest rates (Allen et al., 2004). To account for investor characteristics that affect winning bids, we apply buyer fixed effects $I_{l}$. Our identification strategy improves upon prior literature by allowing variation within the large, medium, and small categories of investors. 
Buyer fixed effects control for unobserved characteristics that are unique to each investor whereas the previous literature does so only by the volume of liens purchased.

Liens not purchased at auction by private investors are purchased by the county at 18 percent. We treat these liens as sold to the county. This treatment avoids issues with selection of liens. Since matching rules themselves affect liens returned to the counties, including in such an analysis only those liens sold to investors does not fully answer the question of the effect of matching rules on tax-delinquent property-owner costs.

\section{RESULTS AND ROBUSTNESS CHECKS}

Results are summarized in Table 4. Note that model specifications in that table progressively include more determinants of auction winning bids. The results are robust to the

TABLE 4: Empirical Results - Unrestricted Sample

\begin{tabular}{|c|c|c|c|c|c|c|c|c|c|c|}
\hline Y: Interest Rate & $\begin{array}{l}\text { Coefficient } \\
\text { OLS }\end{array}$ & & $\begin{array}{l}\text { Coefficient } \\
\text { OLS }\end{array}$ & & $\begin{array}{l}\text { Coefficient } \\
\text { OLS }\end{array}$ & & $\begin{array}{c}\text { Coefficient } \\
\text { OLS }\end{array}$ & & $\begin{array}{l}\text { Coefficient } \\
\text { OLS }\end{array}$ & \\
\hline English - No Matching & $\begin{array}{l}-1.680 \\
(0.430)\end{array}$ & $* * *$ & $\begin{array}{l}-1.055 \\
(0.365)\end{array}$ & $* * *$ & $\begin{array}{l}-2.178 \\
(0.493)\end{array}$ & $* * *$ & $\begin{array}{l}-2.272 \\
(0.943)\end{array}$ & $* *$ & $\begin{array}{l}-2.094 \\
(0.855)\end{array}$ & $* *$ \\
\hline $\begin{array}{l}\text { Delinquent Tax Bill } \\
\text { (\$ Thousands) }\end{array}$ & $\begin{array}{l}-0.001 \\
(0.011)\end{array}$ & & $\begin{array}{c}0.003 \\
(0.005)\end{array}$ & & $\begin{array}{c}0.002 \\
(0.005)\end{array}$ & & $\begin{array}{c}0.002 \\
(0.004)\end{array}$ & & $\begin{array}{c}0.003 \\
(0.004)\end{array}$ & \\
\hline $\begin{array}{l}\text { Est. Market Value } \\
\text { (\$ Thousands) }\end{array}$ & $\begin{array}{l}-0.002 \\
(0.000)\end{array}$ & $* * *$ & $\begin{array}{l}-0.001 \\
(0.000)\end{array}$ & $* * *$ & $\begin{array}{l}-0.001 \\
(0.000)\end{array}$ & $* * *$ & $\begin{array}{l}-0.001 \\
(0.000)\end{array}$ & $* * *$ & $\begin{array}{l}-0.001 \\
(0.000)\end{array}$ & $* * *$ \\
\hline Residential Improved & $\begin{array}{l}-3.065 \\
(0.252)\end{array}$ & $* * *$ & $\begin{array}{l}-1.629 \\
(0.192)\end{array}$ & $* * *$ & $\begin{array}{l}-1.549 \\
(0.201)\end{array}$ & $* * *$ & $\begin{array}{l}-1.548 \\
(0.205)\end{array}$ & $* * *$ & $\begin{array}{l}-0.565 \\
(0.220)\end{array}$ & $* *$ \\
\hline Vacant & $\begin{array}{l}5.696 \\
(0.424)\end{array}$ & $* * *$ & $\begin{array}{c}2.601 \\
(0.294)\end{array}$ & $* * *$ & $\begin{array}{c}2.530 \\
(0.272)\end{array}$ & $* * *$ & $\begin{array}{c}2.639 \\
(0.262)\end{array}$ & $* * *$ & $\begin{array}{l}-0.083 \\
(0.495)\end{array}$ & \\
\hline Late Offer & $\begin{array}{c}0.372 \\
(0.349)\end{array}$ & & $\begin{array}{c}0.131 \\
(0.182)\end{array}$ & & $\begin{array}{c}0.130 \\
(0.190)\end{array}$ & & $\begin{array}{c}0.182 \\
(0.442)\end{array}$ & & $\begin{array}{c}0.359 \\
(0.529)\end{array}$ & \\
\hline $\begin{array}{c}\text { Spatial Lag } \\
\text { Of Winning Bid }\end{array}$ & - & & - & & - & & - & & $\begin{array}{c}0.701 \\
(0.104)\end{array}$ & $* * *$ \\
\hline $\begin{array}{l}\text { Buyer Fixed Effects } \\
\text { Township Fixed Effects } \\
\text { Year Fixed Effects }\end{array}$ & $\begin{array}{l}\text { No } \\
\text { No } \\
\text { No }\end{array}$ & & $\begin{array}{l}\text { Yes } \\
\text { No } \\
\text { No }\end{array}$ & & $\begin{array}{l}\text { Yes } \\
\text { Yes } \\
\text { No }\end{array}$ & & $\begin{array}{l}\text { Yes } \\
\text { Yes } \\
\text { Yes }\end{array}$ & & $\begin{array}{l}\text { Yes } \\
\text { Yes } \\
\text { Yes }\end{array}$ & \\
\hline $\begin{array}{l}\mathrm{N} \\
\mathrm{R}-\text { Squared }\end{array}$ & $\begin{array}{c}127,073 \\
0.402\end{array}$ & & $\begin{array}{c}127,073 \\
0.633\end{array}$ & & $\begin{array}{c}127,073 \\
0.680\end{array}$ & & $\begin{array}{c}127,073 \\
0.694\end{array}$ & & $\begin{array}{c}127,073 \\
0.721\end{array}$ & \\
\hline
\end{tabular}

Notes: Errors Clustered at the township level. ***,*** indicates statistical significance at the $10 \%, 5 \%$, and $1 \%$ levels.

inclusion/exclusion of other determinants of winning bids. The preferred specification, which includes the spatial lag of the dependent variable, suggests that liens sold under a standard English auction receive winning bids that are 2.1 percentage points lower than winning bids auctioned under an English-matching design. The signs on control variables are as expected. Increases in estimated market value and residential improved properties receive higher prices or lower winning bids. 
One potential weakness of the identification strategy is the treatment of liens returned to the county. It is possible that differences in the probability of sale between designs bias the estimated effect of matching rules on winning bids. Intuitively, matching rules in a sequential common-value English auction should not affect a bidder's decision on whether to bid; therefore matching rules should not affect the probability of a lien being returned to the county. Unsold liens tend to have undesirable property characteristics: This is true under both sets of English auction rules examined here. Thus, conditioned on a given property, bidder characteristics and the matching rule applied should not affect the probability of sale. If our hypothesis is correct, we should see no impact of matching rules on the probability of sale. We test this hypothesis by specifying the following logit model:

$$
\begin{aligned}
& \text { Sold }_{l}=\beta_{1} E_{l}+\beta_{2} X_{l}^{\prime}+T_{l}+\lambda_{t}+\varepsilon \\
& \text { If } \quad \text { Sold }_{l} \succ 0 \quad \text { Sold }_{l}=0 \text { otherwise. }
\end{aligned}
$$

The outcome variable, Sold ${ }_{l}$, is a dummy variable indicating whether investor property was sold at auction. The value of one indicates the county sells the lien to an investor and zero when the lien is purchased by the county. The variable, $E_{l}$, is equal to one if the lien was offered at the English nonmatching design and zero otherwise. $X_{l}$ is a vector of property characteristics for lien $l$ that includes information on the delinquent tax bill, estimated market value, and property type. Township fixed effects are included to control for property location. Year fixed effects are included to account for trends in tax lien sales unique to the year in which the tax lien was held.

Table 5 presents results. Our results suggest that the standard English design does not appear to affect the probability of sale when compared to the English-matching design. The coefficient on English nonmatching is not statistically different from zero.

Auction rules do not allow liens to be sold at a rate above 18 percent. It is possible that liens not sold to investors would sell at a rate above 18 percent if auction rules allowed. Instead, liens not purchased by investors are retained by the county and charged the maximum interest of 18 percent. To test the sensitivity of our results to the auction rule not allowing liens to be sold at a rate above 18 percent, we exclude liens returned to the county and rerun the analysis. We present in Table 6, several specifications that include different levels of fixed effects and exclude from the sample liens returned to the county. The results from the last column of Table 6 are consistent in significance, sign and magnitude with those presented in the final column of Table 4.

(C) Southern Regional Science Association 2013. 
TABLE 5: Empirical Results - Logit

\begin{tabular}{|c|c|c|c|}
\hline Y: One if lien was Sold & Coefficient & & $\begin{array}{c}\Delta \text { in } \\
\text { Probability }\end{array}$ \\
\hline English - No Matching & $\begin{array}{l}0.0826 \\
(0.338)\end{array}$ & & 0.004 \\
\hline $\begin{array}{l}\text { Delinquent Tax Bill } \\
\text { (\$ Thousands) }\end{array}$ & $\begin{array}{l}-0.0281 \\
(0.040)\end{array}$ & & -0.0015 \\
\hline $\begin{array}{l}\text { Est. Market Value } \\
\text { (\$ Thousands) }\end{array}$ & $\begin{array}{c}0.014 \\
(0.002)\end{array}$ & $* * *$ & 0.001 \\
\hline Residential Improved & $\begin{array}{c}2.312 \\
(0.250)\end{array}$ & $* * *$ & 0.123 \\
\hline Vacant $\sim$ & $\begin{array}{l}-0.794 \\
(0.152)\end{array}$ & $* * *$ & -0.042 \\
\hline Late Offer $\sim$ & $\begin{array}{l}-0.195 \\
(0.230)\end{array}$ & & -0.01 \\
\hline $\begin{array}{l}\text { Township Fixed Effects } \\
\text { Year Fixed Effects }\end{array}$ & $\begin{array}{l}\text { Yes } \\
\text { Yes }\end{array}$ & & \\
\hline $\begin{array}{l}\text { N } \\
\text { Iterations } \\
\text { Log-Likelihood Function } \\
\quad \text { Psuedo R-Squared }\end{array}$ & $\begin{array}{c}126,976 \\
8 \\
-20,860.8 \\
0.4699\end{array}$ & & \\
\hline
\end{tabular}

Note: Errors clustered at the township level. $\sim \mathrm{dy} / \mathrm{dx}$ is for discrete change of dummy from 0 to 1 . The township of Big Rock in Kane County ( 97 observations) is excluded since all liens were sold in that location and no liens were returned to the county. These observations were excluded as they perfectly predict the sale to private investors. ${ }^{*}, * *, * * *$ indicates statistical significance at the $10 \%, 5 \%$, and $1 \%$ levels. 
TABLE 6: Empirical Results - Sold to Investors

\begin{tabular}{|c|c|c|c|c|c|c|c|c|c|c|}
\hline Y: Interest Rate & $\begin{array}{c}\text { Coefficien } \\
\text { OLS } \\
\end{array}$ & & $\begin{array}{l}\text { Coefficient } \\
\text { OLS } \\
\end{array}$ & & $\begin{array}{c}\text { Coefficient } \\
\text { OLS } \\
\end{array}$ & & $\begin{array}{l}\text { Coefficient } \\
\text { OLS } \\
\end{array}$ & & $\begin{array}{l}\text { Coefficient } \\
\text { OLS } \\
\end{array}$ & \\
\hline English - No Matching & $\begin{array}{l}-1.961 \\
(0.419)\end{array}$ & $* * *$ & $\begin{array}{l}-1.237 \\
(0.409)\end{array}$ & $* * *$ & $\begin{array}{l}-2.548 \\
(0.540)\end{array}$ & $* * *$ & $\begin{array}{l}-2.305 \\
(0.973)\end{array}$ & $* *$ & $\begin{array}{l}-1.828 \\
(0.867)\end{array}$ & $* *$ \\
\hline $\begin{array}{l}\text { Delinquent Tax Bill } \\
\text { (\$ Thousands) }\end{array}$ & $\begin{array}{l}-0.005 \\
(0.007)\end{array}$ & & $\begin{array}{c}0.002 \\
(0.005)\end{array}$ & & $\begin{array}{c}0.001 \\
(0.005)\end{array}$ & & $\begin{array}{c}0.001 \\
(0.004)\end{array}$ & & $\begin{array}{c}0.002 \\
(0.004)\end{array}$ & \\
\hline $\begin{array}{l}\text { Est. Market Value } \\
\text { (\$ Thousands) }\end{array}$ & $\begin{array}{l}-0.001 \\
(0.000)\end{array}$ & $* * *$ & $\begin{array}{l}-0.001 \\
(0.000)\end{array}$ & $* * *$ & $\begin{array}{l}-0.001 \\
(0.000)\end{array}$ & $* * *$ & $\begin{array}{l}-0.001 \\
(0.000)\end{array}$ & $* * *$ & $\begin{array}{l}-0.001 \\
(0.000)\end{array}$ & $* * *$ \\
\hline Residential Improved & $\begin{array}{l}-2.003 \\
(0.231)\end{array}$ & $* * *$ & $\begin{array}{l}-1.438 \\
(0.188)\end{array}$ & $* * *$ & $\begin{array}{l}-1.332 \\
(0.198)\end{array}$ & $* * *$ & $\begin{array}{l}-1.317 \\
(0.206)\end{array}$ & $* * *$ & $\begin{array}{l}-0.052 \\
(0.231)\end{array}$ & \\
\hline Vacant & $\begin{array}{c}4.479 \\
(0.408)\end{array}$ & $* * *$ & $\begin{array}{c}3.083 \\
(0.335)\end{array}$ & $* * *$ & $\begin{array}{l}3.035 \\
(0.306)\end{array}$ & $* * *$ & $\begin{array}{c}3.163 \\
(0.299)\end{array}$ & $* * *$ & $\begin{array}{l}-0.206 \\
(0.547)\end{array}$ & \\
\hline Late Offer & $\begin{array}{c}0.209 \\
(0.345)\end{array}$ & & $\begin{array}{c}0.132 \\
(0.203)\end{array}$ & & $\begin{array}{c}0.109 \\
(0.214)\end{array}$ & & $\begin{array}{c}0.166 \\
(0.456)\end{array}$ & & $\begin{array}{c}0.382 \\
(0.579)\end{array}$ & \\
\hline $\begin{array}{c}\text { Spatial Lag } \\
\text { Of Winning Bid }\end{array}$ & $\begin{array}{l}- \\
-\end{array}$ & & $\begin{array}{l}- \\
-\end{array}$ & & $\begin{array}{l}- \\
-\end{array}$ & & $\begin{array}{l}- \\
-\end{array}$ & & $\begin{array}{c}0.884 \\
(0.113)\end{array}$ & $* * *$ \\
\hline $\begin{array}{l}\text { Buyer Fixed Effects } \\
\text { Township Fixed Effects } \\
\text { Year Fixed Effects } \\
\end{array}$ & $\begin{array}{l}\text { No } \\
\text { No } \\
\text { No } \\
\end{array}$ & & $\begin{array}{l}\text { Yes } \\
\text { No } \\
\text { No } \\
\end{array}$ & & $\begin{array}{l}\text { Yes } \\
\text { Yes } \\
\text { No } \\
\end{array}$ & & $\begin{array}{l}\text { Yes } \\
\text { Yes } \\
\text { Yes } \\
\end{array}$ & & $\begin{array}{l}\text { Yes } \\
\text { Yes } \\
\text { Yes } \\
\end{array}$ & \\
\hline $\begin{array}{l}\mathrm{N} \sim \\
\mathrm{R}-\text { Squared }\end{array}$ & $\begin{array}{c}115,235 \\
0.272\end{array}$ & & $\begin{array}{c}115,235 \\
0.444\end{array}$ & & $\begin{array}{c}115,235 \\
0.526\end{array}$ & & $\begin{array}{c}115,235 \\
0.547\end{array}$ & & $\begin{array}{c}115,235 \\
0.600\end{array}$ & \\
\hline
\end{tabular}

Notes: Errors Clustered at the township level. *,**,*** indicates statistical significance at the $10 \%, 5 \%$, and $1 \%$ levels.

We run further robustness checks to determine sensitivity of the estimate to spurious auction results. We were able to identify one subsample of our data that appeared to be problematic. In 2007, the average of winning bids in Kane County was an interest rate of 15.6 percent. In the same year, 83 percent of tax liens sold in Kane County were sold at the maximum interest rate of 18 percent. While we were puzzled by the auction results, previous literature suggests the results are due to inefficient rules on matching (Milgrom, 2004). It is also possible that anti-competitive behavior was the direct cause. Recent guilty pleas in New Jersey suggest that this type of behavior was not unheard of in the industry during the study period (Department of Justice, 2011). Regardless of the cause, the 2007 auction results for Kane County were very different than for other counties in the same year. To test the sensitivity of our findings, we excluded from the sample liens offered during the 2007 Kane County auction. Table 8 presents the estimated effect of matching rules on winning bids including liens returned to the county. The results are consistent in significance, sign to our prior findings, but the magnitude of the estimate is reduced to 1.26 percentage points, which the results were partially driven by the inclusion of the 2007 Kane County tax-lien sale results. We ran several specifications excluding other counties and years, the estimates were unaffected by sample selection and were identical to those of Table 7. For this paper, we interpret the Table 7 results. 
TABLE 7: Empirical Results - Excluding Kane County 2007

\begin{tabular}{|c|c|c|c|c|c|c|c|c|c|c|}
\hline Y: Interest Rate & $\begin{array}{c}\text { Coefficient } \\
\text { OLS } \\
\end{array}$ & & $\begin{array}{c}\text { Coefficient } \\
\text { OLS } \\
\end{array}$ & & $\begin{array}{c}\text { Coefficient } \\
\text { OLS } \\
\end{array}$ & & $\begin{array}{c}\text { Coefficient } \\
\text { OLS } \\
\end{array}$ & & $\begin{array}{c}\text { Coefficient } \\
\text { OLS } \\
\end{array}$ & \\
\hline English - No Matching & $\begin{array}{l}-0.932 \\
(0.378)\end{array}$ & $* *$ & $\begin{array}{l}-0.290 \\
(0.238)\end{array}$ & & $\begin{array}{l}-1.265 \\
(0.285)\end{array}$ & $* * *$ & $\begin{array}{l}-1.155 \\
(0.647)\end{array}$ & $*$ & $\begin{array}{l}-1.260 \\
(0.621)\end{array}$ & $* *$ \\
\hline $\begin{array}{l}\text { Delinquent Tax Bill } \\
\text { (\$ Thousands) }\end{array}$ & $\begin{array}{c}0.001 \\
(0.011)\end{array}$ & & $\begin{array}{c}0.005 \\
(0.005)\end{array}$ & & $\begin{array}{c}0.004 \\
(0.005)\end{array}$ & & $\begin{array}{c}0.003 \\
(0.004)\end{array}$ & & $\begin{array}{c}0.004 \\
(0.005)\end{array}$ & \\
\hline $\begin{array}{l}\text { Est. Market Value } \\
\text { (\$ Thousands) }\end{array}$ & $\begin{array}{l}-0.002 \\
(0.000)\end{array}$ & $* * *$ & $\begin{array}{l}-0.001 \\
(0.000)\end{array}$ & $* * *$ & $\begin{array}{l}-0.001 \\
(0.000)\end{array}$ & $* * *$ & $\begin{array}{l}-0.001 \\
(0.000)\end{array}$ & $* * *$ & $\begin{array}{l}-0.001 \\
(0.000)\end{array}$ & $* * *$ \\
\hline Residential Improved & $\begin{array}{l}-3.354 \\
(0.262)\end{array}$ & $* * *$ & $\begin{array}{l}-1.881 \\
(0.233)\end{array}$ & $* * *$ & $\begin{array}{l}-1.768 \\
(0.227)\end{array}$ & $* * *$ & $\begin{array}{l}-1.751 \\
(0.232)\end{array}$ & $* * *$ & $\begin{array}{l}-0.982 \\
(0.213)\end{array}$ & $* * *$ \\
\hline Vacant & $\begin{array}{c}5.761 \\
(0.424)\end{array}$ & $* * *$ & $\begin{array}{c}2.625 \\
(0.287)\end{array}$ & $* * *$ & $\begin{array}{c}2.596 \\
(0.265)\end{array}$ & $* * *$ & $\begin{array}{c}2.635 \\
(0.264)\end{array}$ & $* * *$ & $\begin{array}{c}0.761 \\
(0.348)\end{array}$ & $* *$ \\
\hline Late Offer & $\begin{array}{c}0.623 \\
(0.348)\end{array}$ & $*$ & $\begin{array}{c}0.351 \\
(0.167)\end{array}$ & $* *$ & $\begin{array}{c}0.366 \\
(0.124)\end{array}$ & $* * *$ & $\begin{array}{c}0.413 \\
(0.280)\end{array}$ & & $\begin{array}{c}0.625 \\
(0.277)\end{array}$ & $* *$ \\
\hline $\begin{array}{c}\text { Spatial Lag } \\
\text { Of Winning Bid }\end{array}$ & $\begin{array}{l}- \\
-\end{array}$ & & $\begin{array}{l}- \\
-\end{array}$ & & $\begin{array}{l}- \\
-\end{array}$ & & $\begin{array}{l}- \\
-\end{array}$ & & $\begin{array}{c}0.482 \\
(0.063)\end{array}$ & $* * *$ \\
\hline $\begin{array}{c}\text { Buyer Fixed Effects } \\
\text { Township Fixed Effects } \\
\text { Year Fixed Effects } \\
\end{array}$ & $\begin{array}{l}\text { No } \\
\text { No } \\
\text { No } \\
\end{array}$ & & $\begin{array}{l}\text { Yes } \\
\text { No } \\
\text { No } \\
\end{array}$ & & $\begin{array}{l}\text { Yes } \\
\text { Yes } \\
\text { No } \\
\end{array}$ & & $\begin{array}{l}\text { Yes } \\
\text { Yes } \\
\text { Yes } \\
\end{array}$ & & $\begin{array}{l}\text { Yes } \\
\text { Yes } \\
\text { Yes } \\
\end{array}$ & \\
\hline $\begin{array}{l}\mathrm{N} \sim \\
\mathrm{R} \text {-Squared }\end{array}$ & $\begin{array}{c}123,425 \\
0.449\end{array}$ & & $\begin{array}{c}123,425 \\
0.689\end{array}$ & & $\begin{array}{c}123,425 \\
0.725\end{array}$ & & $\begin{array}{c}123,425 \\
0.734\end{array}$ & & $\begin{array}{c}123,425 \\
0.745\end{array}$ & \\
\hline
\end{tabular}

Notes: Errors Clustered at the township level. *,**,*** indicates statistical significance at the $10 \%, 5 \%$, and $1 \%$ levels.

Finally, since the spatial lag variable is endogenous (Anselin, 2002), we used an instrumental variables approach to solve the correlation between the spatial lag variable and the error term. We found the results to be qualitatively identical to the OLS results for our variable of interest (English nonmatching). These results are available upon request.

\section{CONCLUSION}

In this study, we estimate the associated effect of matching rules on tax-lien sale auction results. We find matching rules do not affect the probability of sale (local-government tax-lien sales revenue) but appear to yield higher winning bids (delinquent property-owner costs). Allowing investors to match bids appears to increase tax-delinquent property-owner costs by 20 percent. This paper is the first to estimate the effect of differences in tax-lien sale auction design on the probability of sale and winning bids. The contribution of this paper is to empirically test the hypothesis put forth by Milgrom (2004). Our results supports Milgrom's untested hypothesis and provides an estimated of the magnitude of the difference.

Our discussions with county treasurers led us to believe that the choice of auction design and matching rules was adopted by county treasurers to reduce the administrative burden of conducting tax sales, and not in any way to affect winning bids. Still, we are cautious in interpreting our results as the effect of matching rules on auction outcomes. We recognize this as a limitation of our paper. The data that we used simply could not address a county's selection of 
auction designs. In any event, we hope future research will inform this discussion by identifying the causal impact of auction design on auction outcomes.

Regardless, we believe the findings of this paper advance the research topic in important ways. We address concerns of spurious results by running multiple specifications over different sub-samples. We control for an array of both observable and unobservable characteristics that affect auction results. Our analysis includes controls for both unobserved variation over time and unobserved township characteristics. Furthermore, we are the first to include buyer fixed effects, and our research approach accounts for time-invariant buyer characteristics that could be driving auction results.

Our findings imply that, relative to standard English auctions, English-matching auctions are associated with an increase of $\$ 117$ in the liability of a typical tax-delinquent property owner. This finding is especially important in light of conditions like the Great Recession, during which additional tax-delinquent property-owner costs undoubtedly contribute to poorer long-term outcomes, such as tax foreclosure or prolonged property-tax delinquency. Poor economic and housing market conditions throughout the United States suggest an analysis of delinquent property-tax costs for local governments and property owners is important. Local governments facing declining revenues from other sources would benefit from an auction design that provides more revenues. Tax-delinquent property owners facing persistent high rates of unemployment and declining home values would benefit from an auction design that provides the lowest interest rates. This paper allows policy-makers to calculate the trade-off between auction designs so they may make better-informed decisions when considering changes to auction design. The results suggest the standard English auction design is associated with lower interest rates when compared to English matching design. Thus, local governments may be able to reduce the burden generated by auction design by simply changing auction rules on matching. Furthermore, research can inform not only tax-lien sale auction design, but also the potential costs associated with poorly designed auctions more generally.

\section{REFERENCES}

Allen, Marcus. T., Sheri Faircloth, and Ali Nejadmalayeri. (2004) "Factors Influencing Interest Rates on Delinquent Property Tax Certificates," Journal of Real Estate Finance and Economics, 28, 19-36.

Anselin, Luc. (2002) "Under the Hood: Issues in Specification and Interpretation of Spatial Regression Models," Agricultural Economics, 27, 247-267.

. (2003) "Spatial Externalities, Spatial Multiplier, and Spatial Econometrics," International Regional Science Review, 26, 153-166.

Anselin, Luc and Daniel Arribas-Bel. (2013) "Spatial Fixed-Effects and Spatial Dependence in a Single Cross-Section," Papers in Regional Science, 92, 3-17.

Ashenfelter, Orley. (1989) "How Auctions Work for Wine and Art," Journal of Economic Perspectives, 3, 23-36.

Ashenfelter, Orley and David Genesove. (1992) "Testing for Price Anomalies in Real-Estate Auction," American Economic Review, 82, 501-505.

Carlson, T. L. (1951) “The Illinois Military Tract: A Study of Land Occupation, Utilization and Tenure," Illinois Studies in the Social Sciences, 32(2), 1-218.

(C) Southern Regional Science Association 2013. 
Conrad, James and Larry DeBoer. (1990) "The 1989 Property Tax Sale in Marion County: Results of a Survey of Investors," unpublished paper from Purdue University.

DeBoer, L., Conrad, J., \& McNamara, K. T. (1992). Property tax auction sales. Land Economics, 72-82.

Dye, R. F., \& McGuire, T. J. (1997). The effect of property tax limitation measures on local government fiscal behavior. Journal of Public Economics, 66(3), 469-487.

Kagel, John H. and Dan Levin. (2002) Common Value Auctions and the Winner's Curse. Princeton University Press: Princeton, NJ.

Kerkstra, Patrick. (2013) "Property-tax Debt Is Ravaging Philadelphia," Philadelphia Inquirer. March 14.

McAfee, R. Preston and John McMillan. (1987) "Auctions and Bidding," Journal of Economic Literature, 25, 699-738.

Menezes, Flavio M. and Paulo Klinger Monteiro. (2005) An Introduction to Auction Theory. Oxford University Press: Oxford, UK.

Mezzitti, Cluadio. (2011) "Sequential Auctions with Informational Externalities and Aversion to Price Risk: Decreasing and Increasing Price Sequences," The Economic Journal, 121, 990-1016.

Milgrom, Paul. (2004) Putting Auction Theory to Work. Cambridge University Press: Cambridge, UK.

Milgrom, Paul R. and Robert J. Weber. (1982) "A Theory of Auctions and Competitive Bidding," Econometrica, 50, 1089-1122.

Swierenga, Robert P. (1974) "Acres for Cents: Delinquent Tax Auctions in Frontier Iowa," Agricultural History, 48, 247-266.

U.S. Department of Justice, Financial Fraud Enforcement Task Force. (2011) Three New Jersey Investors Plead Guilty to Bid Rigging at Municipal Tax Lien Auctions. Office of Public Affairs: Washington, D.C., August 24.

(C) Southern Regional Science Association 2013. 